\title{
Alternative sugarcane production for conservation of sandy soils: sugarcane straw, intercropping and nitrogen
}

\section{Alternativa conservacionista de produção da cana-de-açúcar em solos arenosos: palhiço, consórcio e nitrogênio}

\author{
Leandro Flávio Carneiro ${ }^{* *}$ (D) Ricardo Augusto de Oliveira ${ }^{1}$ (D) Heroldo Weber ${ }^{1}$ (D) Edelclaiton Daros ${ }^{1}$, \\ Guilherme Souza Berton ${ }^{1}$ (D), Fábio Vieira Rodrigues ${ }^{2}$
}

1'Universidade Federal do Paraná/UFPR, Departamento de Fitotecnia e Fitossanidade/DFF, Curitiba, PR, Brasil

2Fundação da Universidade Federal do Paraná/FUNPAR, Curitiba, PR, Brasil

*Corresponding author: leandrocarneiro@ufpr.br

Received in April 22, 2020 and approved in June 26, 2020

\begin{abstract}
The expansion of sugarcane cultivation in the Center-South region of Brazil has led to the use of, mainly, areas with low-yielding sandy soils. In this context, the objectives of this study were to evaluate the maintenance of the sugarcane straw, Brachiaria grass intercropping in sugarcane fields and nitrogen fertilization and on sandy soils in the state of Paraná. The field experiment was installed in the Paranavaí-PR city, at a unit of the Interuniversity Network for the Development of the Sugarcane Sector (RIDESA). The Soil was classified as Latossolo Vermelho-amarelo distrófico. The treatments in the plant cane stage, consisting of four nitrogen rates $(0,50$, 100 and $150 \mathrm{~kg} \mathrm{ha}^{-1}$ ) and monoculture or Brachiaria grass intercropping in sugarcane fields were arranged in a $4 \times 2$ factorial design. At plant cane harvest, the effect of unremoved straw was included as a new factor to be evaluated in the ratoon crops. The treatments in the ratoon crops were arranged in a $4 \times 2 \times 2$ factorial design, consisting of four nitrogen rates $\left(0,50,100\right.$ and $\left.150 \mathrm{~kg} \mathrm{ha}^{-1}\right)$, monoculture or Brachiaria grass intercropping in sugarcane fields and the presence or removal sugarcane straw. The sugarcane straw on soil surface can increase the agronomic development of sugarcane and, the other hands, Brachiaria grass intercropping in sugarcane fields can reduce. Sugarcane was responsive to $\mathrm{N}$ rates and, in the highest rates, compensated the sugarcane straw absence and reduced Brachiaria grass intercropping competition.
\end{abstract}

Index terms: Light soils; brachiaria; management and conservation.

\begin{abstract}
RESUMO
A expansão da cultura da cana-de-açúcar na região Centro-Sul tem sido predominantemente em solos arenosos com baixo potencial produtivo. Os objetivos deste trabalho foram avaliar a manutenção do palhiço, consórcio da cana com a braquiária e doses de nitrogênio no cultivo da cana em solo arenoso do Paraná. O experimento foi instalado em condições de campo, situado no município de Paranavaí-PR, na unidade da Rede Interinstitucional para o Desenvolvimento do Setor Sucroenergético (Ridesa). O solo foi classificado como sendo um Latossolo Vermelho-amarelo distrófico. Os tratamentos na cana-planta foram constituídos de um fatorial $4 \times 2$, sendo quatro doses de nitrogênio $\left(0,50,100\right.$ e $\left.150 \mathrm{~kg} \mathrm{ha}^{-1}\right)$ e cana consorciada e não consorciada com braquiária. Na ocasião da colheita da cana-planta, implementou-se o palhiço como novo fator para ser avaliado na canasoca. Os tratamentos da cana-soca foram constituídos de um fatorial $4 \times 2 \times 2$, sendo quatro doses de nitrogênio $(0,50,100$ e 150 $\mathrm{kg} \mathrm{ha}^{-1}$ ), cana consorciada e não consorciada com braquiária, e uso do palhiço e o não uso do palhiço. A manutenção do palhiço na superfície do solo pode aumentar o desenvolvimento agronômico da cana e, por outro lado, o consórcio de capim braquiária pode reduzir. A cana-de-açúcar foi responsiva às doses de $\mathrm{N}$ e, nas maiores doses, compensou a ausência do palhiço e reduziu a competição entre as espécies.
\end{abstract}

Termos para indexação: Solos leves; braquiária; manejo e conservação.

\section{INTRODUCTION}

Brazil is the world's largest producer of sugarcane, where this country is the biggest sugar producer and the second position when consider the ethanol production. In the Center South region, which accounts for more than $90 \%$ of the Brazilian sugarcane production, the crop has expanded into low-yielding environments, mainly of degraded pasture areas (Carvalho, 2015; Donagemma et al., 2016). 
In this region, light soils, which belong to the sand and loamy sand textural classes, are predominant. They have a weak, small granular or simple-grain structure, low water retention, high permeability, low aggregate stability and high erosion susceptibility. The waterphysical relations of these soils are influenced by the clay fraction mineralogy and particle size distribution of the sand fraction. In general, the higher the kaolinite content and particle heterogeneity of the sand fraction, the greater the susceptibility to surface sealing, particle packing (densification), hard to extremely hard consistency when dry and high friability when wet (Donagemma et al., 2016; Giarola et al., 2009).

In light soils, the fertility tends to be limited, with low levels of soil organic matter (SOM), and cation exchange capacity (CEC) and high aluminum saturation, while on the other hand, phosphorus (P) adsorption and potential acidity are lower. Therefore, acidity correctives (liming), phosphorus (P fertilization) and gypsum must be applied at lower rates and higher frequency (Donagemma et al., 2016; Novais et al., 2007).

In view thereof, conservation-focused agricultural practices have to be implemented to avoid soil and water losses by erosion, avoid soil drying and high temperatures that affect the microbial biomass activity, maintain and/ or increase the nutrient use efficiency, nutrient cycling, carbon input in the soil, and increasing the soil production potential in the long term. In sugarcane fields, mainly where mechanical management is used, the no-tillage (direct planting) system can be implemented, with planting under the trash of a previous unburned ratoon crop and stubble of crops or green manure residues (Bolonhezi; Gonçalves, 2015; Canellas et al., 2007; Cherubin et al., 2019; Santos Júnior et al., 2015; Signor et al., 2016; Tavares et al., 2010; Oliveira et al., 2017; Tenelli et al., 2019).

The sugarcane sector has been increased in mechanical harvesting without prior burning, resulting in large amount of sugarcane straw on the soil surface and increase in $\mathrm{C}$ and $\mathrm{N}$ stocks (Cerri et al., 2011; Oliveira et al., 2017; Cherubin et al., 2019; Tenelli et al., 2019). With objective to quantify tillage intensity and straw removal levels on soil organic carbon (SOC) stocks, Tenelli et al. (2019) indicate that a conversion from conventional tillage to reduced tillage system without straw removal would result in SOC gains of 0.31 and $0.21 \mathrm{Mg} \mathrm{ha}^{-1}$ years ${ }^{-1}$ in the $0-10 \mathrm{~cm}$ from the sandy loam and clayey soil, respectively. The SOC accretion contributes to soil organic matter formation, witch so important to improving cation exchange capacity, soil physical quality and indirectly preserve water, mainly in sandy tropical soils (Donagemma et al., 2016; Tenelli et al., 2019).

An important factor of the soil-plant interactions of a production system analyzed in this study is the nitrogen management. The reason is that, apart from the high $\mathrm{N}$ demand of the crop, nitrogen also plays a key role in the decomposition of plant residues and carbon humification in the soil, resulting in an effective increase in SOM (Cherubin et al., 2019; Potrich et al., 2014; Yamaguchi et al., 2017).

In the short term, high responses to the increase in $\mathrm{N}$ rates are expected. Sugarcane straw has a C:N ratio of around 100:1, which promotes immobilization of $\mathrm{N}$ in the soil and results in small amounts of nitrogen being mineralized for the following crop season (Cantarella, 2007; Fortes et al., 2012; Vitti et al., 2010). Another factor that can contribute to the increase in the demand for $\mathrm{N}$ by sugarcane is the greater water availability provided by the residues in cover, which contribute to reduce evaporation losses, reducing soil temperature and wind action, resulting in greater stalk productivity (Resende et al., 2019; Vitti et al., 2010).

Together with the no-tillage system, the effect of unremoved straw and nitrogen application by mineral fertilization, the additional possibility of intercropping sugarcane with Brachiaria species must be tested, even though these grasses are considered a main weed in sugarcane fields (Galon et al., 2011; Toledo et al., 2017). Brachiaria species are well adapted to tropical and subtropical conditions and have a high potential for nutrient cycling and biomass input (Wutke; Calegari; Wildner, 2014). This can favor an increase in contents of carbon and nutrient, in particular of the most mobile in the soil and, consequently, raise the SOM levels in light soils.

In view of the socioeconomic importance of the sugarcane, its expansion in sandy soils and the low productivity in these environments, not only in the Northwest of Paraná, but also in the Center South and Matopiba (i.e., the Cerrado biome in the states of Maranhão, Tocantins, Piauí and Bahia) region of Brasil, this study was based on the hypothesis that (i) permanence of sugarcane straw reflect in higher sugarcane yield, (ii) Brachiaria grass intercropping in sugarcane fields interfere on sugarcane yield and (iii) the management nitrogen fertilization ensure high sugarcane yield. In this context, the objectives of this study were to evaluate the maintenance of the sugarcane straw, Brachiaria grass intercropping in sugarcane fields and nitrogen fertilization on sandy soils in the state of Paraná. 


\section{MATERIAL AND METHODS}

The field experiment was installed in ParanavaíPR city, at a unit of the Interuniversity Network for the Development of the Sugarcane Sector (RIDESA), (lat $23^{\circ} 4^{\prime} 55^{\prime \prime}$; longitude $52^{\circ} 27^{\prime} 55^{\prime \prime}$; $446 \mathrm{~m}$ asl). The soil was classified as a Latossolo Vermelho-amarelo distrófico (Soil Survey Staff, 2014). Before planting sugarcane, some soil samples were collected to characterized the fertility and physical attributes at $0-20$ and $20-40 \mathrm{~cm}$ soil depth (Table 1), according to the methodology described by (Empresa Brasileira de Pesquisa Agropecuária Embrapa, 2009). The soil micronutrients B, Cu, Fe, Mn and $\mathrm{Zn}$ of the $0-20 \mathrm{~cm}$ layer were also analyzed, with contents of, respectively, $0.22,0.56,21.7,34.8$ and 0.64 $\mathrm{mg} \mathrm{dm}^{-1}$. Before implementing the experiment, Brachiaria grass (Urochloa decumbens) had been planted at the RIDESA unit for 32 years. The rainfall distribution and temperature during the experimental period are shown in Figure 1.

Table 1: Soil chemical properties and texture in the surface and subsurface layer of a Latossolo Vermelhoamarelo distrófico dystrophic, in Paranavaí -PR.

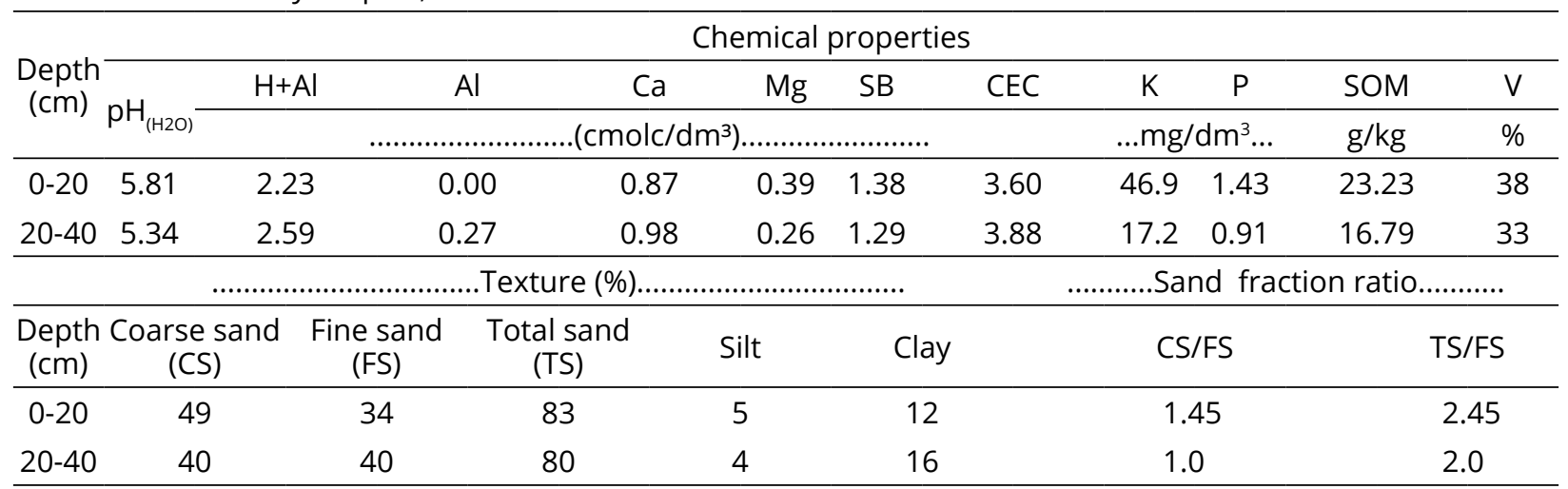

${ }^{1} \mathrm{P}$ and $\mathrm{K}=$ Melhich-1; $\mathrm{Ca}, \mathrm{Mg}$ and $\mathrm{Al}=\mathrm{KCl} 1 \mathrm{~mol} \mathrm{~L}{ }^{-1} ; \mathrm{H}+\mathrm{Al}=$ calcium acetate and soil organic matter $(\mathrm{SOM})=\mathrm{Walkley}-\mathrm{Black} . \mathrm{CEC}$ : cation exchange capacity.

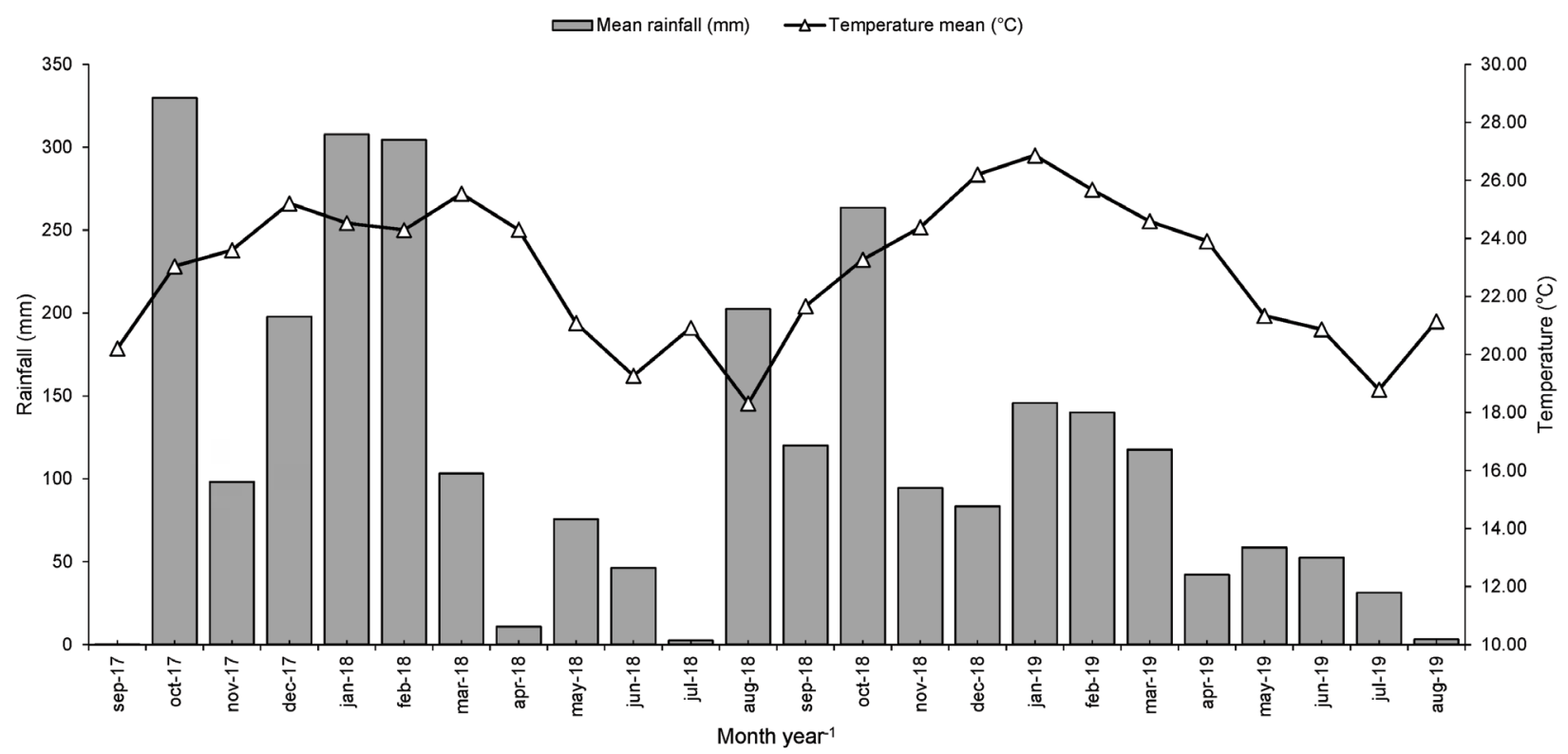

Figure 1: Rainfall and temperature during the experimental period and historical means at an experimental unit of RIDESA, in Paranavaí-PR. Experimental start/end dates: sugarcane planting (09/30/17), cane plant harvest $(08 / 11 / 18)$ and ratoon harvest $(01 / 08 / 19)$. 
The experiment was installed in a randomized block in a factorial $4 \times 2$ design with three replications, consisting of the factors four nitrogen rates $(0,50,100$ and $150 \mathrm{~kg} \mathrm{~N} \mathrm{ha}^{-1}$ ), half of which was applied in the planting furrow and the other half at 45 days after planting (DAP). The second factor was the intercrop cultivation in sugarcane: monoculture or intercropped with Brachiaria grass. The sugarcane plots consisted of five rows with length of $10 \mathrm{~m}$, at an inter-row spacing of $1.5 \mathrm{~m}$, covering a total area of $75 \mathrm{~m}^{2}$. The plot mean area was considered the 3 central rows with length of $8 \mathrm{~m}$. The sugarcane variety RB 867515 was planted manually, characterized by high responsiveness in agro-industrial yield and indicated for more restrictive environments, such as sandy soils (Daros et al., 2010), using 18 setts per meter.

The data of the cane plant were based on the mean of two plots. At plant cane harvest, the effect of unremoved straw was included as a new factor to be evaluated in the ratoon crops. The residues were ground and weighed and an amount of $7.5 \mathrm{Mg} \mathrm{ha}^{-1}$ distributed on the plot surface (Sá et al., 2015). To this end, the ratoon cane treatments were arranged in a factorial $4 \times 2 \times 2$ design, consisting of four nitrogen rates $\left(0,50,100\right.$ and $\left.150 \mathrm{~kg} \mathrm{ha}^{-1}\right)$, sugarcane monoculture or intercropped with Brachiaria grass, (grown by natural sprouting of Brachiaria species between sugarcane rows) and the effect of straw removal or nonremoval. The nitrogen source applied to the cane plant and ratoon crops was ammonium sulfate with $21 \%$ NH4-N and $16 \% \mathrm{SO}_{4}{ }^{2}$. The cover fertilizations were carried out manually, on the soil surface, without incorporation, at 10 $\mathrm{cm}$ from the planting line.

Before setting up the experiment, Brachiaria grass was mowed and, at the time of regrowth, 20 days later, dried with glyphosate at a rate of $3.0 \mathrm{~L} \mathrm{ha}^{-1}$ on the sugarcane monoculture plots. Dolomitic limestone $(2.0 \mathrm{Mg}$ $\mathrm{ha}^{-1}$ ) was also broadcast on the entire area, with a relative neutralizing value of $95 \%$, without incorporation. At 20 days after these agricultural practices, the untilled soil was furrowed to plant sugarcane.

Fertilization at sugarcane planting consisted of $180 \mathrm{~kg} \mathrm{P}_{2} \mathrm{O}_{5}$ ha $^{-1}$ contained in simple superphosphate, $84 \mathrm{~kg} \mathrm{~K}_{2} \mathrm{O} \mathrm{ha}^{-1}$ in potassium chloride, $58 \mathrm{~kg} \mathrm{MgO} \mathrm{ha}^{-1}$ in magnesium sulfate, $2.0 \mathrm{~kg} \mathrm{~B} \mathrm{ha}^{-1}$ in boric acid, $2.5 \mathrm{~kg} \mathrm{Cu}$ $\mathrm{ha}^{-1}$ in copper sulfate and $4.0 \mathrm{~kg} \mathrm{Zn} \mathrm{ha} \mathrm{Ka}^{-1}$ in zinc sulfate. Side dressing, at 45 days after emergence, consisted of 56 $\mathrm{kg} \mathrm{K}_{2} \mathrm{O} \mathrm{ha}^{-1}$ in potassium chloride, with $60 \% \mathrm{~K}_{2} \mathrm{O}$. For the ratoon crop, side dressing contained nitrogen, potassium and boron. The $\mathrm{N}$ rate treatments were applied 45 days after ratooning, together with potassium (applied at 140 $\mathrm{kg} \mathrm{K}_{2} \mathrm{O} \mathrm{ha}^{-1}$ in potassium chloride) and boron $\left(2 \mathrm{~kg} \mathrm{~B} \mathrm{ha}^{-1}\right.$ in boric acid). After cane plant harvest, the chemical soil analysis indicated low levels of these elements at a distance of $15 \mathrm{~cm}$ from the sugarcane rows.

After sugarcane sprouting, a strip of at least 20 $\mathrm{cm}$ on either side of the plant rows was maintained weedand grass-free, by applying $1.3 \mathrm{~L} \mathrm{ha}^{-1}$ Combine*500 SC, a selective herbicide, recommended for weed control in sugarcane. In the sugarcane/Brachiaria intercropping treatments, after natural regrowth and grass growth between sugarcane rows, sub-rates of $0.3 \mathrm{~L} \mathrm{ha}^{-1}$ Mesotriona, a selective herbicide for maize and sugarcane with systemic action of post-emergent weed control, were applied to delay growth and decrease interspecies competition. In the monoculture treatments, sugarcane was maintained weed-free with the recommended Mesotriona dose.

At harvest, the sugarcane variables tons of cane per hectare (TCH), tons of pol per hectare (TPH), POL percentage (POL) and total recoverable sugars (TRS) were assessed, expressed in kilograms of sugar per tons of cane. The variables TRS and POL were determined in a sample of 10 stalks from the assessed area, which were detrashed and removed from the sugarcane at the natural break-point of the cane. To estimate $\mathrm{TCH}$ and sugarcane straw, the number of stalks in the evaluated area of each plot was counted and, based on the weight of 10 stalks, the mean weight per stalk was estimated and extrapolated to 1 ha. These variables were determined by the methodology of Bidoia and Bidoia (2010).

The results were subjected to analysis of variance (ANOVA), using the SISVAR software (Ferreira, 2011) and the means compared by the $\mathrm{F}$ and Tukey tests at $5 \%$ probability for qualitative factors and by regression for the quantitative factors and, in case of significant interaction, the factors were partitioned.

\section{RESULTS AND DISCUSSION}

For the variables analyzed in plant cane cycle, an interaction was observed between the factors under study for sugarcane straw, TCH and TPH. In the analysis of the effect of nitrogen rates in each intercropping treatment, a significant linear effect in all variables was observed (Figure 2A, 2B e 2C), showing greater increase in Brachiaria grass intercropping in sugarcane fields, as the angular coefficients of the straight line shows, which were on average twice as high as in sugarcane monoculture, resulting in no difference for TPH at a nitrogen rate of $150 \mathrm{~kg} \mathrm{ha}^{-1}$ (Figure 2C). The factors had no effect on the variables POL and TRS, with respective overall means of $15.8 \%(\mathrm{C} . \mathrm{V} .=2.7 \%)$ and $155.30(\mathrm{C} . \mathrm{V} .=2.4 \%)$. 

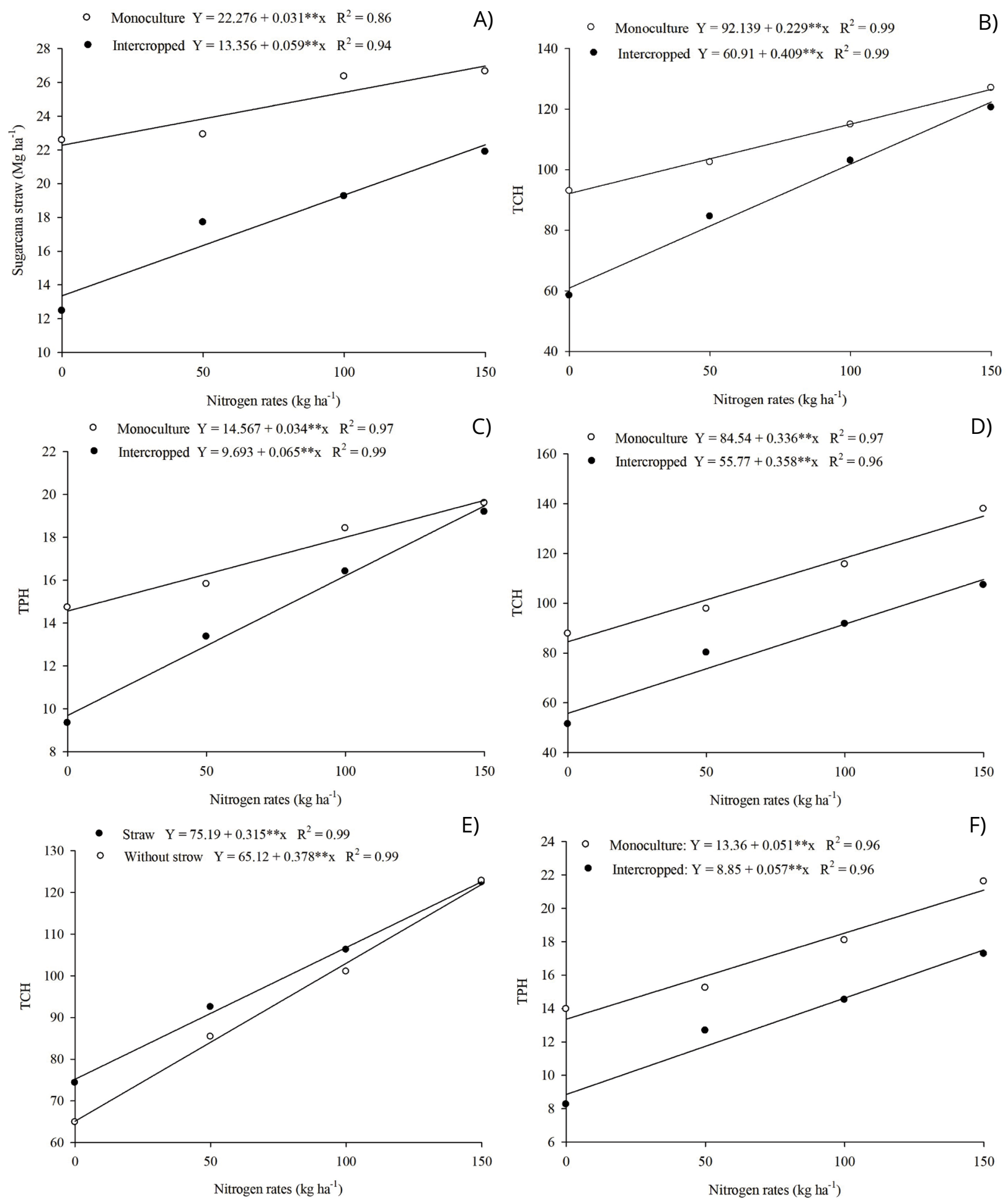

Figure 2: Sugarcane straw $(A)(C . V .=10,9 \%)$, tons of cane per hectare $(T C H)(B)(C . V .=3,7 \%)$ and tons of Pol per hectare (TPH) (C) (C.V. = 4,7\%) in plant cane and tons of cane per hectare (TCH) (C.V. $=3,1 \%)(\mathrm{D}$ and E), tons of Pol per hectare (TPH) (C.V. $=4,5 \%)(\mathrm{F}$ and $\mathrm{G})$ and sugarcane straw $(\mathrm{H})$ in ratoon cane on response to nitrogen rates on a Latossolo Vermelho-amarelo distrófico típico with a sandy texture, in Paranavaí-PR.

Continue... 


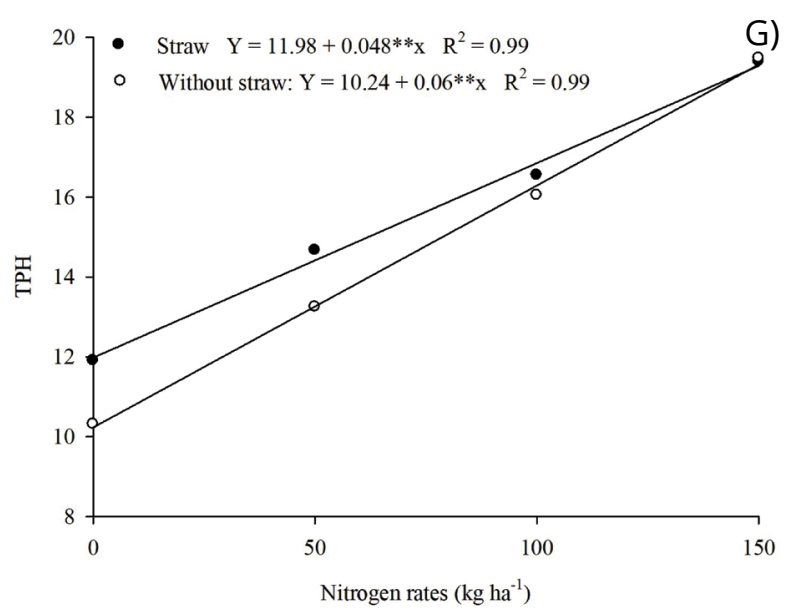

Figure 2: Continuation...

For the analyzed ratoon crop variables, was observed a double interaction between $\mathrm{N}$ rates and Brachia grass intercropping sugarcane fields and $\mathrm{N}$ rates with sugarcane straw to TCH and TPH. In the analyses of the response to nitrogen rates, a significant linear increase in the variables was observed (Figure 2D, 2E, 2F, 2G and $2 \mathrm{H}$ ). It was observed that, regardless of the $\mathrm{N}$ rates, lower averages for TCH and TPH in the treatments with intercropping (Figures 2D and 2F), which was not repeated in the treatments with the sugarcane straw, which were higher only in the lowest doses of N (Figures 2E and 2G). Intercropping with Brachiaria had an isolated effect on sugarcane straw and TRS and was greater in sugarcane monoculture (Table 2). For the variable POL, no significant effect of the studied factors was observed, with a mean of $15.83 \%$ (C.V. $=2.9 \%)$.

Table 2: Sugarcane straw $\left(\mathrm{kg} \mathrm{ha}^{-1}\right)$ and (total recoverable sugars) TRS of ratoon cane intercropped with Brachiaria grass on a Latossolo Vermelho-amarelo distrófico with a sandy texture, in Paranavaí -PR.

\begin{tabular}{ccc}
\hline Intercropping & Sugarcane straw & TRS \\
\hline with & $20.842 \mathrm{~B}$ & $153 \mathrm{~B}$ \\
without & $23.329 \mathrm{~A}$ & $156 \mathrm{~A}$ \\
C.V. (\%) & 10.3 & 3.1 \\
\hline
\end{tabular}

Means followed by the same letter in a column do not differ by Tukey's test at 5\% probability.

No removal straw in sugarcane increased the means of TCH and TPH at the lowest nitrogen rates (Figures 2E and 2G). The amount of trash used in this experiment was in the mean lower than in commercial

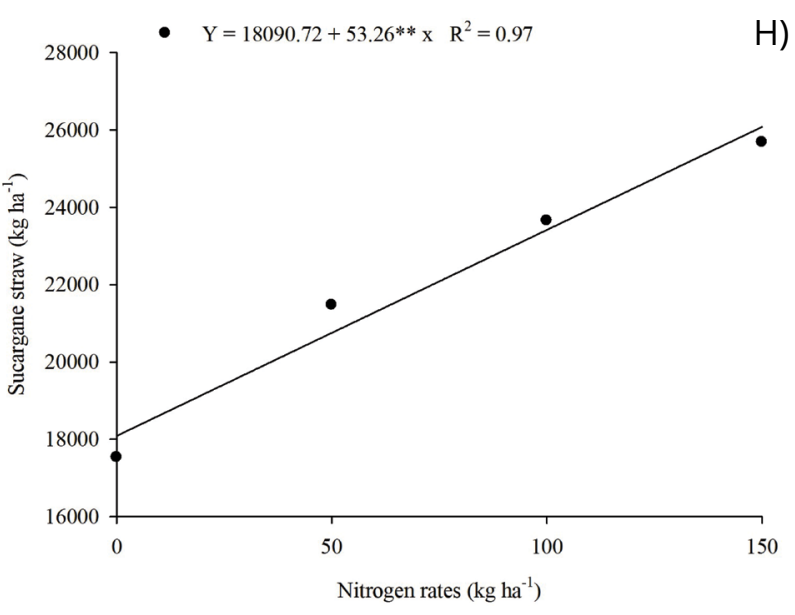

areas, where an average quantity of $10 \mathrm{tha}^{-1}$ to $20 \mathrm{tha}^{-1}$ dry matter is left on the surface (Leal et al., 2013). The contribution of $\mathrm{N}$ from sugarcane straw was evaluated during three ratoon crop seasons by Ferreira et al. (2017), in the state of São Paulo, and was observed that the average trash- $\mathrm{N}$ recovery after this period was $7,6 \mathrm{~kg} \mathrm{ha}^{-1}$ (or $16.2 \%$ of the initial $\mathrm{N}$ content in trash), with the remaining trash-N being incorporated into soil organic matter reserves. Despite the low contribution of $\mathrm{N}$ from sugarcane straw reported, especially in the early years, Cherubin et al. (2019) using a literature review and two field studies, observed that removing $12 \mathrm{Mg} \mathrm{ha}^{-1}$ of strow, the potential $\mathrm{N}, \mathrm{P}, \mathrm{K}, \mathrm{Ca}, \mathrm{Mg}$ and $\mathrm{S}$ removal was $69,7,92,45,16$ e $14 \mathrm{~kg} \mathrm{ha}^{-1}$, respectively. These results indicate that a significant amount of the nutrients is returned to the soil by maintaining straw on the soil surface.

No removal straw probably also contributed to reduce water losses by evaporation, decrease the temperature in the uppermost soil layers and delay Brachiaria sprouting and establishment, reducing the competition between the species (Donagemma et al., 2016; Resende et al., 2019). Sandy soils with a coarse sand/fine sand ratio higher than 1.0, as observed in the surface layer of this experiment (Table 1), tend to have greater particle heterogeneity and higher susceptibility to the occupation of empty spaces between larger grains by smaller particles (packing), reducing the porous space (Donagemma et al., 2016). In addition, in case of drying, the consistency of these soils tends to become hard, but friable when moist. In this context, the straw probably contributed to reduce the dryness of the soil and favor the root growth of the cane (Freitas et al., 2017). 
The means of sugarcane straw (Figure 2A and Table 2), TCH (Figures 2B and 2D) and TPH (Figures 2C and $2 \mathrm{~F}$ ) were lower in the intercropping treatment with Brachiaria grass, which emerged naturally between the sugarcane rows, without, however, affecting the technological variables of the harvested product, except for TRS in ratoon cane (Table 2). The reduction in biometric variables can be explained by the competition for water, radiation and nutrients between the species. The degree of interference between sugarcane and Brachiaria grass depends on the density and distribution of the Brachiaria plants between the sugarcane rows, since the sugarcane crop row was maintained weed-free, even free of Brachiaria within at least $20 \mathrm{~cm}$ from the crop row. In addition, after planting the plant cane and the during the ratoon cycle, the climatic conditions were favorable for Brachiaria germination and growth in the first five months (Figure 1), corresponding to a major part of the critical period of weed control in sugarcane fields (Galon et al., 2011).

It is worth bearing in mind that sugarcane is a water and nutrient-demanding crop, above all with regard to nitrogen. However, with the increasing $\mathrm{N}$ rates, the competition intensity between species decreased, resulting in equal values of TPH at the highest $\mathrm{N}$ rate in plant cane (Figure 2C). Therefore, the highest nitrogen rates favored the establishment of the species until the canopy between the sugarcane rows was closed, when the incidence of solar radiation declined, causing the death of the Brachiaria plants. In the treatments with lower nitrogen rates, the competition between species persisted until sugarcane harvest, resulting in a lower productivity of plant cane and ratoon crops.

The Brachiaria grass intercropping in sugarcane fields is a challenging proposal. The need to reinforce conservationist practices in the cultivation of sugarcane in sandy soils (Donagemma et al., 2016), authors proposed such a condition. Despite the lower performance of the cane, relatively high productivity was observed in the highest doses of N (Figures 2B, 2C, 2D and 2F). Forage grasses has been used in integrated cropping system in consortium or in rotation with maize or soybean to reduce $\mathrm{N}$ loss, increase nutrient cycling and nutrient use efficiency (Rosolem et al., 2017; Shelton; Jacobsen; McCulley, 2018). However, to our knowledge, there are no studies assessing sugarcane yield changes induced by intercropping with Brachiaria grass throughout crop season. It is expected that, throughout the sugarcane crops and cycles, increase SOM, nutrient cycling and water and soil retention. Factors such as the distance from the Brachiaria to the cane row, Brachiaria grass persistence by sugarcane straw and herbicide management must be elucidated.
Despite several studies show that $\mathrm{C}$ inputs annually added to soil through sugarcane straw resulted in soil $\mathrm{C}$ and N stocks accretion (Cerri et al., 2011; Cherubin et al., 2018; Oliveira et al., 2017; Tenelli et al., 2019), the linear responses of sugarcane to $\mathrm{N}$ rates show that, in order to ensure high sugarcane yield harvested without fire dispatch and intercropping Brachiaria grass, at least in the first years, need to apply high $\mathrm{N}$ rates. The low SOM content (Table 1), Brachiaria grasses intercropping in sugarcane fields, reduced soil tillage (direct furrowing), the high $\mathrm{N}$ demand of sugarcane, $\mathrm{N}$ losses by leaching into the sandy soils and decomposition of plant material with a high $\mathrm{C} / \mathrm{N}$ ration (Brachiaria and trash), explain these results (Luz et al., 2017; Vitti et al., 2010).

Sugarcane straw has a C:N ratio of around 100:1, which promotes immobilization of $\mathrm{N}$ in the soil and results in small amounts of nitrogen being mineralized for the following crop season (Fortes; Trivelin; Vitti, 2012). Decomposition of sugarcane harvest residue in different climatic zones at Australian was measured by Robertson and Thorburn (2007) and observed that, in addition to the $\mathrm{C}: \mathrm{N}$ ratio, rainfall and temperature were correlated with sugarcane straw decomposition. Others factors such as lignin or polyphenol content affect the microbial activity and sugarcane straw decomposition (Young; Ritz, 2000).

Considering the socio-economic importance of sugarcane culture for Brazil and its expansion in sandy soils in the Center-South region, future studies should focus on managing conservationist practices. The sugarcane straw has been consolidated as an important factor that contribute to improving soil quality and reducing fertilizers consumption, however, straw removal for bioelectricity, cellulosic ethanol, or other bio-products requires further studies, mainly in the Midwest, South and Northeast regions of Brazil, which contribute to equating such practices. Soil cover plants and green manure in the areas of implantation and reform of sugarcane are recommended, especially in soil susceptible to erosion and low fertility, however the recommendation of high biomass production and nutrient cycling plants, such as Brachiaria grass intercropping in sugarcane fields, is not considered by technicians, since it is one of the main cane weeds. Factors such as wider spacing, selective herbicides and herbicide management in Brachiaria grass intercropping sugarcane fields that mitigate species competition can interfere in intensity and interference period between species. However, future studies need to be developed to maximize this practice, resulting over time, increase in soil quality, productivity, sugarcane longevity y and reduction of environmental impact. The handling of $\mathrm{N}$ stands out in 
this scenario, beyond yours high sugarcane demand and soil dynamics, it is a key nutrient in residues decomposition and $\mathrm{C}$ humidification in the soil.

\section{CONCLUSIONS}

Conclusions drawn from this study show that the maintenance of the sugarcane straw on soil surface can increase the agronomic development of sugarcane and, on the other hands, Brachiaria grass intercropping in sugarcane fields can reduce. Sugarcane was responsive to $\mathrm{N}$ rates and, in the highest rates, compensated the sugarcane straw absence and reduced Brachiaria grass intercropping competition. Based on the dates, these findings highlight the need to study management strategies that make the conservation of sugarcane feasible in sandy soils. We believe that the factors studied in this work can contribute to direct conservation strategies for sugarcane cultivation in sandy soils, mainly if them were conducted in long term.

\section{ACKNOWLEDGMENTS}

The authors would like to thank the Graduate Program in Plant Production of the Federal University of Paraná for the post-doctoral fellowship of Professor Leandro Flávio Carneiro and the Interuniversity Network for the Development of the Sugarcane Sector for granting the permission to use the experimental unit of ParanavaíPR for the installation, conduction and evaluation of the experiment.

\section{REFERENCES}

BIDOIA, M. A. P.; BIDOIA, M. A. P. Instalação, condução e colheita de experimentos. In: DINARDO-MIRANDA, L. L.; VASCONCELOS, A. C. M.; LANDELL, M. G. A. Canade-açúcar. Campinas: Instituto Agronômico, 2010. v. 1, p.809-819.

BOLONHEZI, D.; GONÇALVES, N. H. Sucessão e rotação de culturas na produção de cana-de-açúcar. In: BELARDO, G. C.; CASSIA, M. T.; SILVA, R. P. Processos agrícolas e mecanização da cana-de-açúcar. Jaboticabal, Associação Brasileira de Engenharia Agrícola, 2015. p.219-241.

CANELLAS, L. P. et al. Estoque e qualidade de matéria orgânica de um solo cultivado com cana-de-açúcar por longo tempo. Revista Brasileira de Ciência do Solo, 31(2):331-340, 2007.

CANTARELLA, H. Nitrogênio. In: NOVAIS, R. F. et al. Fertilidade do solo. Viçosa, Sociedade Brasileira de Ciência do Solo, 2007. p.375-470.
CARVALHO, L. C. C. Cenários e estratégias do setor sucroenergético: Sustentabilidade socioeconômica. In: SILVA, F. C.; ALVES, B. J. R.; FREITAS, P. L. Sistema de produção mecanizada da cana-de-açúcar integrada à produção de energia e alimentos. Brasília: Embrapa, v.1, 2015. p.20-45.

CERRI, C. C. et al. Effect of sugarcane harvesting systems on soil carbon stocks in Brazil: An examination of existing data. European Journal of Soil Science, 62(1):23-28, 2011.

CHERUBIN, M. R. et al. Sugarcane Straw Removal: Implications to Soil Fertility and Fertilizer Demand in Brazil. BioEnergy Research, 12:888-900, 2019.

DAROS, E. et al. Catálogo nacional de variedades "RB" de cana-de-açúcar. Curitiba: Editora Ridesa, 2010. 136p.

DONAGEMMA, G. K. et al. Caracterização, potencial agrícola e perspectivas de manejo de solos leves no Brasil. Pesquisa Agropecuária Brasileira, 51(9):1003-1020, 2016.

EMPRESA BRASILEIRA DE PESQUISA AGROPECUÁRIA EMBRAPA. Manual de análises químicas de solos, plantas e fertilizantes. Brasília, Embrapa informação tecnológica, 2009. 627p.

FORTES, C.; TRIVELIN, P. C. O.; VITTI, A. C. Long-term decomposition of sugarcane harvest residues in São Paulo state, Brazil. Biomass and Bioenergy, 42:189-198, 2012.

FERREIRA, D. A. et al. Contribution of $\mathrm{N}$ from green harvest residues for sugarcane nutrition in Brazil. Global Change Biology Bioenergy, 8:859-866, 2017.

FERREIRA, D. F. Sisvar: A computer statistical analysis system. Ciência e Agrotecnologia, 35(6):1039-1042, 2011.

FREITAS, P. L. et al. Comportamento de solos de textura superficial arenosa influenciado pela produção mecanizada de cana-de-açúcar. In: SILVA, F. C.; ALVES, B. J. R.; FREITAS, P. L. Sistema de produção mecanizada de cana-de-açúcar integrada a produção de energia e alimentos. Brasília: Embrapa, v.2, 2017. p.476-519.

GALON, L. et al. Interferência da Brachiaria brizantha nas características morfológicas da cana-de-açúcar. Planta Daninha, 29(5):1029-1036, 2011.

GIAROLA, N. F. B. et al. Mineralogia e cristalografia da fração argila de horizontes coesos de solos nos tabuleiros costeiros. Revista Brasileira de Ciência do Solo, 33(1):33-40, 2009.

LEAL, M. R. L. V. et al. Sugarcane straw availability, quality, recovery and energy use: A literature review. Biomass Bioenergy, 53:11-19, 2013. 
LUZ, P. H. C. et al. Nutrição mineral e fertilização em cana-deaçúcar. In: SILVA, F.C.; ALVEEI, B. J. R.; FREITAS, P. L. Sistema de produção mecanizada da cana-de-açúcar integrada à produção de energia e alimentos. Brasília: Embrapa, v.2, 2017. p.656-730.

NOVAIS, R. F.; SMYTH, T. J.; NUNES, F. N. Fósforo. In: NOVAIS, R. F. et al. Fertilidade do solo. Viçosa: Sociedade Brasileira de Ciência do Solo, v.1, 2007. p.471-550.

OLIVEIRA, D. M. S. et al. Predicting soil C changes over sugarcane expansion in Brazil using the DayCent model. Global Change Biology Bioenergy, 9(9):1436-1446, 2017.

POTRICH, D. C. et al. Decomposição de resíduos culturais de cana-de-açúcar submetidos a diferentes doses de nitrogênio. Semina: Ciências Agrárias, 35(4):1751- 1760, 2014.

RESENDE, M. et al. Pedologia, Fertilidade, água e planta: Interrelações e aplicações. Lavras: Editora UFLA, 2019. 254p.

ROBERTSON, F. A.; THORBURN, P. J. Decomposition of harvest residue in different climatic zones. Australian Journal of Soil Research, 45:1-11, 2007.

ROSOLEM, C. A. et al. Enhanced plant rooting and crop system management for improved $\mathrm{N}$ use efficiency. Advantages in Agronomy, 146:205-239, 2017.

SÁ, M. A. C. et al. Manejo do palhiço residual na cultura da cana-de-açúcar no Cerrado: Primeira aproximação. Planaltina, DF: Circular Técnica 27/ Embrapa, 2015. 5p.

SANTOS JÚNIOR, J. D. G. et al. Sistema plantio direto de canade-açúcar no Cerrado. Planaltina, DF: Circular Técnica 30/ Embrapa, 2015. Available in: <https://ainfo.cnptia.embrapa. br/digital/bitstream/item/131276/1/cirtec-30.pdf>. Access in: December 20, 2019.

SHELTON, R. E.; JACOBSEN, K. L.; MCCULLEY, R. L. Cover crops and fertilization alter nitrogen loss in organic and conventional conservation agriculture systems. Frontiers in Plant Science, 8:2260, 2018.
SIGNOR, D. et al. Atributos químicos e qualidade da matéria orgânica do solo em sistemas de colheita de cana-deaçúcar com e sem queima. Pesquisa Agropecuária Brasileira, 51(9):1438-1448, 2016.

SOIL SURVEY STAFF. Keys to Soil Taxonomy. 12th. ed. Washington, DC: United States Department of Agriculture, Natural Resources Conservation Service; 2014. 681p.

TAVARES, O. C. H. et al. Crescimento e produtividade da cana planta cultivada em diferentes sistemas de preparo do solo e de colheita. Acta Scientiarum. Agronomy, 32(1): 61-68, 2010.

TENELLI, S. et al. Can reduced tillage sustain sugarcane yield and soil carbon if straw is removed? BioEnergy Research, 12:764-777, 2019

TOLEDO, R. E. B. et al. Biologia e manejo de plantas daninhas em cana-de-açúcar e na sucessão com culturas anuais nas áreas de reforma. In: SILVA, F. C.; ALVES, B. J. R.; FREITAS, P. L. Sistema de produção mecanizada da cana-de-açúcar integrada à produção de energia e alimentos. Brasília: Embrapa, v.2, 2017. p.310-343.

VITTI, A. C. et al. Cana-de-açúcar. Campinas: Instituto Agronômico de Campinas, v.1, 2010. p.239-270.

WUTKE, E. B.; CALEGARI, A.; WILDNER, L. P. Espécies de adubos verdes e plantas de cobertura e recomendações para seu uso. In: LIMA FILHO, F.; AMBROSANO, F. R.; CARLOS, J. A. $D$. Adubação verde e plantas de cobertura no Brasil: Fundamentos e prática. Dourados: Embrapa, v.1, 2014. p.59-167.

YAMAGUCHI, C. S. et al. Decomposição da palha de canade-açúcar e balanço de carbono em função da massa inicialmente aportada sobre o solo e da aplicação de vinhaça. Bragantia, 76(1):135-144, 2017.

YOUNG, I. M.; RITZ, K. Tillage, habitat space and function of soil microbes. Soil and Tillage Research, 53:201-213, 2000. 